\title{
Sociodemographic and Anthropometric Profile of Positive HIV Patients in Early Traditional Treatment: Case of the Bonkoko Center
}

\author{
Ben Ilunga Bulanda', Elvis Tshunza Kateba², Berry Ikolango Bongenia1, \\ Victor Nyiama Kasongo3, Micheline Abiba Kingombe ${ }^{2}$, Erick Ntambwe Kamangu1,4* \\ 1"HIV/AIDS Focus" Research Group, Kinshasa, Democratic Republic of Congo \\ ${ }^{2}$ National Program for the Promotion of Traditional Medicine and Medicinal Plants (PNMT/PM), Ministry of Public Health, \\ Kinshasa, Democratic Republic of Congo \\ ${ }^{3}$ Bonkoko Tradi-Modern Center, Kinshasa, Democratic Republic of Congo \\ ${ }^{4}$ Molecular Biology Service, Department of Basic Sciences, Faculty of Medicine, University of Kinshasa (UNIKIN), \\ Kinshasa, Democratic Republic of Congo \\ Email: *erick.kamangu@unikin.ac.cd
}

How to cite this paper: Bulanda, B.I., Kateba, E.T., Bongenia, B.I., Kasongo, V.N., Kingombe, M.A. and Kamangu, E.N. (2018) Sociodemographic and Anthropometric Profile of Positive HIV Patients in Early Traditional Treatment: Case of the Bonkoko Center. Open Access Library Journal, 5: e4555.

https://doi.org/10.4236/oalib.1104555

Received: March 30, 2018

Accepted: May 18, 2018

Published: May 21, 2018

Copyright $\odot 2018$ by authors and Open Access Library Inc.

This work is licensed under the Creative Commons Attribution International License (CC BY 4.0).

http://creativecommons.org/licenses/by/4.0/

(c) (i) Open Access

\begin{abstract}
Context: In the Democratic Republic of Congo (DRC), the Antiretroviral (ART) drug coverage is still very low throughout the country. Hence, a large number of People Living with HIV (PLHIV) use traditional treatment made from plants to fight the HIV infection and the opportunistic infection associated to it. Objective: The objective of this work was to evaluate the clinical parameters; para clinical and socio-demographic studies at the beginning of treatment of People Living with HIV (PLHIV) who adhere to traditional treatment in Kinshasa. Methods: A cohort study was conducted in the Bonkoko center with a baseline of 3 months; $97 \mathrm{HIV}$ positive patients were included randomly according to the specific inclusion criteria from January 11, 2016 to April 11, 2016. Clinical, biological and socio-demographic parameters were recorded in all patients at baseline. Results: A total of 97 patients were selected for the job. A total of 79 women (81\%) and 18 men (19\%) participated voluntarily. The mean age was $40.8 \pm 10$ years and the most represented age range was 36 - 45 years. The mean Body Mass Index (BMI) is $23.07 \pm 3.8$ at baseline. The married dominated the sample while the dominant religion was the other religions called revival. The level of study that dominated the population was the secondary level. The mean biological values at baseline were as follows: Glycaemia $85 \pm 19 \mathrm{mg} / \mathrm{dl}$; Urea $22.5 \pm 6.66 \mathrm{mg} / \mathrm{dl}$; Creatinine $0.88 \pm 0.22 \mathrm{mg} / \mathrm{dl}$; Total cholesterol $169.6 \pm 37.7 \mathrm{mg} / \mathrm{dl} ;$ HDL $52.6 \pm 15.1$ $\mathrm{mg} / \mathrm{dl}$; LDL $96.4 \pm 31.4 \mathrm{mg} / \mathrm{dl}$; Triglyceride $102.8 \pm 47 \mathrm{mg} / \mathrm{dl}$; SGPT $23.3 \pm$
\end{abstract}


11.1 UI/L; SGOT $22.3 \pm 10 \mathrm{UI} / \mathrm{L}$; Amylase $81.9 \pm 31.1 \mathrm{UI} / \mathrm{L}$; and the median values for CD4 was 220 cells/ml and for the Viral Load was $4.10 \log _{10}$ copies of $\mathrm{RNA} / \mathrm{ml}$. Conclusion: This study showed that patients who adhere to traditional medicine for the treatment of HIV infection are not different from those starting Antiretroviral into modern centers. The patient is in search of wellness and what is better. These patients followed by Traditional Medicine must be considered and taken care of in an integral way like all PLHIV followed by modern medicine.

\section{Subject Areas}

HIV

\section{Keywords}

HIV, Traditional Medicine, Djovikas, PLHIV, Kinshasa

\section{Introduction}

Human Immunodeficiency Virus (HIV) and Acquired Immunodeficiency Syndrome (AIDS) continue to be a major public health problem worldwide. Sub-Saharan Africa remains the region most affected by the epidemic [1]. Nearly two million cases of HIV infection were reported in 2015 [1].

In 2000, the United Nations Millennium Development Declaration aimed to assist Member States in optimizing the use of traditional medicines to contribute to the establishment of a "Health for All in the $21^{\text {st }}$ century" in the Africa region [2]. Since then, different countries have examined the impact of Traditional Medicine in terms of prevention and care for various pathologies, including the HIV infection [2].

In the Democratic Republic of Congo (DRC), the prevalence of HIV infection is $1.2 \%$ for the country as a whole [3]. Since 2002, Anti Retro Virals (ARVs) have been introduced in the DRC for monitoring of people living with HIV (PLHIV) [4]. The goal of this treatment is to reduce morbidity and mortality, achieve and maintain plasma viral suppression, improve immune function and quality of life [4]. Nevertheless, the coverage of these ARVs is still very low across the country; it was less than $20 \%$ for the year 2015 [3]. Hence, a large number of PLHIVs use traditional herbal treatments for HIV infection, as well as associated opportunistic infections [5]. These traditional treatments are very commonly used in the fight against HIV infection in our environment, but there is no scientific data and evidence in our community.

Hence the objective of this work was to evaluate the clinical, paraclinical and sociodemographic parameters of HIV positive patients followed by Traditional Medicine in the beginning of treatment as well as to bring the necessary knowledge in the care of the PLHIV followed by this medicine in Kinshasa, DRC. 


\section{Methods}

\subsection{Frame}

The present work is a cross-sectional presentation at the inclusion period of a cohort conducted in the Bonkoko Traditional Treatment Center in Masina, Kinshasa, from January 11 to April 11, 2016.

\subsection{Patients}

Ninety seven (97) HIV positive patients initiating traditional treatment whose serology was confirmed by HIV rapid serologic tests, signed informed consent prior to the start of sampling, naive of ARV treatment, or discontinued ARV were included. Phytomedicine consumption and participation in the work were entirely voluntary. HIV positive patients younger than 18 years, those who did not sign informed consent, and those who lacked serologic confirmation were not included. The anthropometric, sociodemographic, clinical and paraclinical parameters were collected on the individual files of the patients.

\subsection{Blood Samples}

Five milliliters of blood were collected in a tube with Lithium Heparin anticoagulant and a tube with EDTA anticoagulant from the vein in the elbow fold after signature of informed consent.

\subsection{Statistical}

The data collected were entered on Windows Excel version 2010. The results were expressed as mean \pm standard deviation for the parameters with Gaussian distribution and median [extremes] for those with non-Gaussian distribution. The tables have been reformatted in Excel.

\section{Results}

Of the 97 patients included in this work, 79 (81\%) were female and $18(19 \%)$ male. The average age was $40.8 \pm 10$ years and the most represented age group was between 36 - 45 years old. The average Body Mass Index (BMI) is $23.08 \pm$ 3.8 at baseline. Most patients (67\%) started treatment with a BMI between 18.5 and 24.9. Almost all patients (93\%) started treatment in Clinical Stage II according to the WHO classification. Table 1 presents the anthropometric and clinical data of the population. Almost half of the population (46\%) is married and $43 \%$ are housewives. The highest level of education is high school with $69 \%$. Most patients (77\%) attend revival churches or sects. The first reasons that favored adherence to Traditional Treatment were: 1) the testimony of other patients treated in the center (16\%), 2) the need for healing (14\%), 3) advice from friends (14\%) and 4) curiosity (14\%). Table 2 presents the clinical parameters. The mean values of the biological parameters are respectively: Glycemia $84.95 \pm$ $19.08 \mathrm{mg} / \mathrm{dl}$; Urea $22.47 \pm 6.66 \mathrm{mg} / \mathrm{dl}$; Creatinine $0.88 \pm 0.26 \mathrm{mg} / \mathrm{dl}$; Total Cholesterol $169.6 \pm 37.74 \mathrm{mg} / \mathrm{dl} ;$ HDL $52.75 \pm 15.13 \mathrm{mg} / \mathrm{dl} ; \mathrm{LDL} 96.4 \pm 31.45 \mathrm{mg} / \mathrm{dl}$ 
(Table 3); Triglyceride $102.8 \pm 46.92 \mathrm{mg} / \mathrm{dl}$; SGPT $23.35 \pm 11.11 \mathrm{IU} / \mathrm{L} ; \mathrm{SGOT}$ $22.34 \pm 10.85 \mathrm{IU} / \mathrm{L} ;$ Amylase $81.89 \pm 31.14 \mathrm{IU} / \mathrm{L}$. The median values of CD4 and $\mathrm{CV}$ are respectively 220 cells $/ \mathrm{ml}$ and $4.10 \log _{10}$ copies of $\mathrm{RNA} / \mathrm{ml}$. All paraclinical data are presented explicitly in Table 4.

Table 1. Sociodemographic parameters of patients.

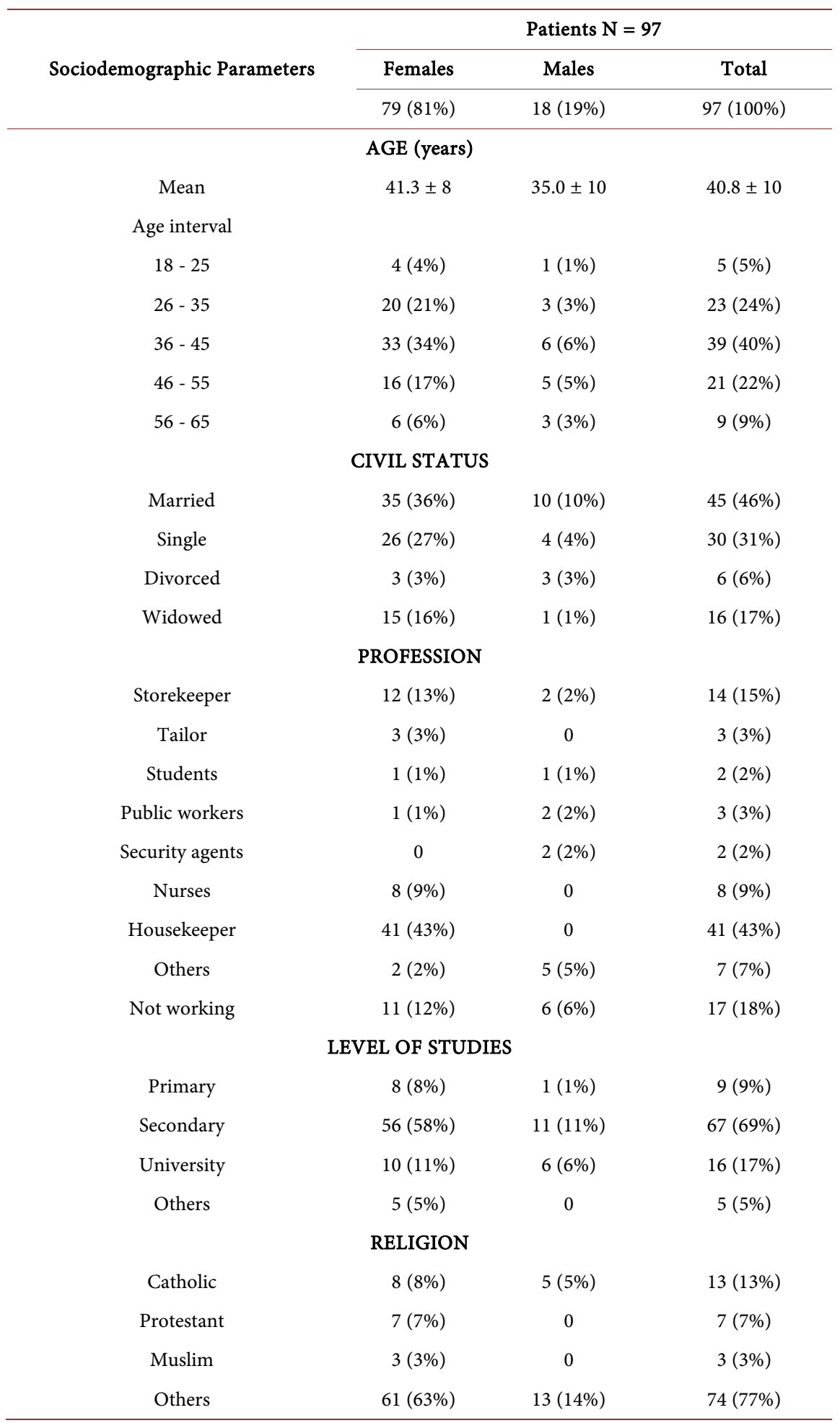


Table 2. Clinical parameters of patients at baseline (D0).

\begin{tabular}{cccc}
\hline \multirow{2}{*}{ Clinical Parameters } & \multicolumn{3}{c}{ Patients } \\
\cline { 2 - 4 } & Females & Males & Total \\
\hline$<18.5$ & BMI & $2(2 \%)$ & $8(8 \%)$ \\
$18.5-24.9$ & $6(6 \%)$ & $13(14 \%)$ & $64(67 \%)$ \\
$25-30$ & $51(53 \%)$ & $3(3 \%)$ & $20(21 \%)$ \\
$>30$ & $17(18 \%)$ & $0(0 \%)$ & $5(5 \%)$ \\
State I & $5(5 \%)$ & & 0 \\
State II & CLINICAL STATE & 0 & $15(15.4 \%)$ \\
State III & $75(77 \%)$ & $3(3 \%)$ & $60(93 \%)$ \\
State IV & $3(3 \%)$ & $0(0 \%)$ & $0(1 \%)$ \\
\hline
\end{tabular}

Table 3. Raison for treatment change.

\begin{tabular}{cccc}
\hline Raison for Treatment change & Females & Males & Total \\
\hline Tired of long lasting treatment & $1(1 \%)$ & 0 & $1(1 \%)$ \\
Need of change & $3(3 \%)$ & $1(1 \%)$ & $4(4 \%)$ \\
Need of well being & $13(14 \%)$ & 0 & $13(14 \%)$ \\
Knowledge & $5(5 \%)$ & $2(2 \%)$ & $7(7 \%)$ \\
Advice from a friend & $11(12 \%)$ & $2(2 \%)$ & $13(14 \%)$ \\
Curiosity & $11(12 \%)$ & $3(3 \%)$ & $14(15 \%)$ \\
Side effects of ARV & $1(1 \%)$ & $2(2 \%)$ & $3(3 \%)$ \\
Finding new things & 0 & $1(1 \%)$ & $1(1 \%)$ \\
Faith & $1(1 \%)$ & 0 & $1(1 \%)$ \\
Naïve of treatment & $4(4 \%)$ & $1(1 \%)$ & $5(5 \%)$ \\
Being invited by the tradipraticien & $1(1 \%)$ & 0 & $1(1 \%)$ \\
Recommendation & $2(2 \%)$ & $1(1 \%)$ & $3(3 \%)$ \\
Testimonies from other patients & $13(14 \%)$ & $2(2 \%)$ & $15(16 \%)$ \\
\hline
\end{tabular}

Table 4. Mean and median values of biological parameters of patients at baseline (D0).

\begin{tabular}{cccc}
\hline Biological Parameters & Mean & $\begin{array}{c}\text { Standard } \\
\text { deviation }\end{array}$ & Median \\
\hline Blood Pressure Systole & 114.12 & 16.27 & 110 \\
Blood Pressure Diastole & 73.14 & 9.90 & 70 \\
Temperature $\left({ }^{\circ} \mathrm{C}\right)$ & 35.55 & 5.11 & 83 \\
Glycaemia $(60-110 \mathrm{mg} / \mathrm{dL})$ & 84.95 & 19.08 & 22 \\
Urea $(15-45 \mathrm{mg} / \mathrm{dL})$ & 22.47 & 6.66 & 0.9 \\
\hline
\end{tabular}




\section{Continued}

\begin{tabular}{cccc}
\hline Total Cholesterol $(110-200 \mathrm{mg} / \mathrm{dL})$ & 169.60 & 37.74 & 171 \\
HDL Cholesterol $(30-70 \mathrm{mg} / \mathrm{dL})$ & 52.75 & 15.13 & 51 \\
LDL Cholesterol $(\leq 160 \mathrm{mg} / \mathrm{dL})$ & 96.4 & 31.45 & 101 \\
Triglyceride $(35-185 \mathrm{mg} / \mathrm{dL})$ & 102.8 & 46.92 & 98 \\
SGPT $(0-31 \mathrm{UI} / \mathrm{L})$ & 23.35 & 11.11 & 21.8 \\
SGOT $(0-41 \mathrm{UI} / \mathrm{L})$ & 22.34 & 10.85 & 19.9 \\
Amylase $(0-95 \mathrm{UI} / \mathrm{L})$ & 81.89 & 31.14 & 78.1 \\
CD4 (cellules/ml) & 246.88 & 136.12 & 220 \\
CV $\left(\log _{10}\right.$ copies of RNA/ml) & 4.22 & 1.30 & 4.10 \\
\hline
\end{tabular}

\section{Discussion}

The objective of this work was to evaluate the clinical, paraclinical and sociodemographic parameters of HIV positive patients followed by Traditional Medicine at the beginning of treatment as well as to bring the necessary knowledge in the management of PVV followed by this medicine in Kinshasa.

The population consisted of 97 patients including 79 women and 18 men, with a sex ratio of $4 / 1$ for women. The most represented age group is between 36 - 45 years with $45 \%$ of cases and an average of $40.79 \pm 10.07$ years. The female predominance corresponds with the data of the literature in our environment [3]-[8]; which stated that HIV infection tends to feminize in sub-Saharan African countries for various reasons. As well as for the age group that is the one where sexual activity is most intense but also because at this age the person tends to become aware of life and become responsible.

Ninety-three percent (93\%) of patients started their treatment in clinical stage 2 according to the WHO classification. The average weight was $62.70 \pm 11.44 \mathrm{~kg}$ and the average BMI was $23.08 \pm 3.79$. These data demonstrate that patients become better aware of the importance of initiating early treatment that involves a favorable therapeutic response for patients.

Nearly half of the patients are married (47\%), followed by single (31\%) and widowed (16\%). Forty-two percent $(42 \%)$ of this population are housewives, $18 \%$ are unemployed, $14 \%$ are shopkeepers and $8 \%$ are nurses. These data correspond to those published by other authors of our environment [7] [8].

The highest level of education is secondary education (high school) with 69\% of the total population, $16 \%$ having a university level and $9 \%$ having a primary school level. Educational attainment also influences reproductive behavior, use of modern contraception, health behavior, and hygiene and nutrition habits. This reveals that all social levels are affected by HIV infection regardless of the level of education of the population [7].

Seventy-seven percent (77\%) of the population attend so-called revival churches; $13 \%$ are Catholic; 7\% are Protestant and 3\% are Muslim. This corroborates with the literature data reported in our medium [3]. 
The majority of patients adhered to traditional treatments because of the testimony of others who, for many, were also followed previously in the same Tradi-modern center, but also by the need to be cured of HIV infection and this is explained by the fact that most patients need a definitive cure in the short term and not a long-term treatment that discourages and depresses as is the case with ARVs.

The mean value of the blood glucose was $84.95 \pm 19.08 \mathrm{mg} / \mathrm{dl}$. This value is in the interval according to the standards $(60-110 \mathrm{mg} / \mathrm{dl})$ [9]. This data is justified by initiating treatment early in clinical stage 2 . It is contrary to other data collected in the cohorts of patients who start treatment in clinical stage 3 or 4 [7] $[8]$.

The mean values of urea and creatinine were $22.47 \pm 6.66 \mathrm{mg} / \mathrm{dL}$ and $0.88 \pm$ $0.22 \mathrm{mg} / \mathrm{dL}$, respectively. These values are in the respective ranges according to the standards (15 - $45 \mathrm{mg} / \mathrm{dl}$ and $0.5-1.5 \mathrm{mg} / \mathrm{dl})$ [9]. These data may also be justified by initiating treatment early in clinical stage 2 . Indeed, at this stage, the clinical signs are not serious. These data are also contrary to other data collected in the cohorts of patients who begin treatment at clinical stage 3 or 4 [7] [8].

The mean value of total cholesterol, HDL, LDL and triglyceride were $169.60 \pm$ $37.74 \mathrm{mg} / \mathrm{dL}, 52.75 \pm 15.13 \mathrm{mg} / \mathrm{dL}, 96.4 \pm 31.35 \mathrm{mg} / \mathrm{dL}$ and $102.8 \pm 46.92 \mathrm{mg} / \mathrm{dL}$, respectively. These values are in the respective ranges according to the standards (110 - $200 \mathrm{mg} / \mathrm{dl}, 30-70 \mathrm{mg} / \mathrm{dl}, \leq 160 \mathrm{mg} / \mathrm{dl}$ and $35-185 \mathrm{mg} / \mathrm{dl})$ [9]. These data may also be justified by initiating treatment early in clinical stage 2 . They corroborate those later published in our setting even for patients who begin treatment in clinical stage 3 or 4 [7] [8] [10].

Mean transaminase values, SGPT and SGOT, were $23.35 \pm 11.11 \mathrm{IU} / \mathrm{L}$ and $22.34 \pm 10.85 \mathrm{IU} / \mathrm{L}$, respectively. Although close to the upper limits, these values are in the respective intervals according to the norms $(0-31 \mathrm{UI} / \mathrm{L}$ and $0-41$ $\mathrm{UI} / \mathrm{L})[9]$.

The average value of the amylase was $81.89 \pm 31.14 \mathrm{IU} / \mathrm{L}$. This value tends towards the upper limit of the interval according to the norms (0 - $95 \mathrm{UI} / \mathrm{L})$ [9].

The median CD4 count was 220 cells $/ \mathrm{ml}$ with extremes of 18 and 405 cells $/ \mathrm{ml}$. These low values classify patients in this cohort as eligible for Antiretroviral Therapy (ART) in our setting compared to the national recommendations. Low CD4 values are also described in the literature for patients initiating ART in our environment [6].

The median Viral Load (VL) value was $4.10 \log _{10}$ RNA copies/ml with extremes of $2.16 \log _{10}$ and $7.23 \log _{10}$ RNA copies/ml. These high VL scores rank these patients as ART eligible in our community according to national guidelines. High VL values confirm that patients start treatment often late; they corroborate the literature for patients initiating ART in our environment [6].

\section{Conclusion}

This work has shown that patients who adhere to traditional medicine for the treatment of HIV infection are no different from those initiating antiretrovirals 
in modern centers. All these patients have the same profile as they initiate ARV in modern centers or traditional treatment. Hence, the patients followed by traditional medicine must be considered and taken care of integrally as all the PLHIV followed by modern medicine while avoiding all forms of discrimination and rejection of them by the modern medicine as well as by the community or the society where they are.

\section{Conflict of Interest}

The authors declare that there was no conflict of interest.

\section{References}

[1] United Nation Program against HIV and AIDS (UNAIDS). (2015) 2015 Activities Report on the Fight against AIDS in the World.

[2] World Health Organization (WHO). Stratégie de l'OMS pour la Médecine Traditionnelle pour 2014-2023, Ouagadougou, 2010. http://www.who.int/

[3] (2014) Ministère du Plan et Suivi de la Mise en œuvre de la Révolution de la Modernité et Ministère de la Santé Publique, République Démocratique du Congo. Enquête Démographique et de Santé 2013-2014 (EDS 2013-2014). Rapport.

[4] (2013) Programme National de Lutte contre le VIH/SIDA et les Infections Sexuellement Transmissible (PNLS), Ministère de la Santé Publique, République Démocratique du Congo (RDC). Guide National de Prise en Charge de l'Infection à VIH en RDC. Version revise.

[5] Kamangu, N.E., Nyima, K.V., Kingombe, A.M., Nkutshi, T.W. and Mesia, K.G. (2013) Suivi des Patients VIH Positifs Traités Par la Médecine Traditionnelle à Kinshasa: étude rétrospective des dossiers des patients suivis au Centre BONKOKO. Revue Congolaise des Sciences, 1, 50-59.

[6] Kamangu, N.E., Bulanda, I.B., Bongenia, I.B., Botomwito, T.H., Mvumbi, L.G., De Mol, P., Vaira, D., Hayette, M.-P. and Kalala, L.R. (2015) Virological Profile of Patients Infected with HIV Starting Antiretroviral Treatment in Kinshasa. Open Access Library Journal, 2, e1564. https://doi.org/10.4236/oalib.1101564

[7] Bulanda, I.B., Kamangu, N.E., Bongenia, I.B., Botomwito, T.H., Lusakibanza, M. and Mesia, K.G. Evaluation de l'Indice de Masse Corporelle chez la Personne Vivant avec le VIH suivi à l'Hôpital Provincial Général de Référence de Kinshasa sous ARV. (Under Press)

[8] Bongenia, I.B., Ilombo, L.L., Botomwito, T.H., Bulanda, I.B., Kamangu, N.E., Lusakibanza, M. and Mesia, K.G. (2014) Fréquence du Suivi des Paramètres Biologiques des Patients sous Antirétroviraux à Kinshasa: Cas de l'Hôpital Provincial Général de Référence. Journal des Recherches Biomédicales, 1, 1-6.

[9] Durand, D.V., Le Jeune, C. and Dorosz, Ph. (2011) Guide pratique des médicaments. Maloine 30ème édition.

[10] Bongania, I.B., Bulanda, I.B., Botomwito, T.H. and Kamangu, N.E. Analyse Comparative des Taux Lipidiques Sériques des Personnes Infectées par le VIH à Kinshasa. (Under Press) 